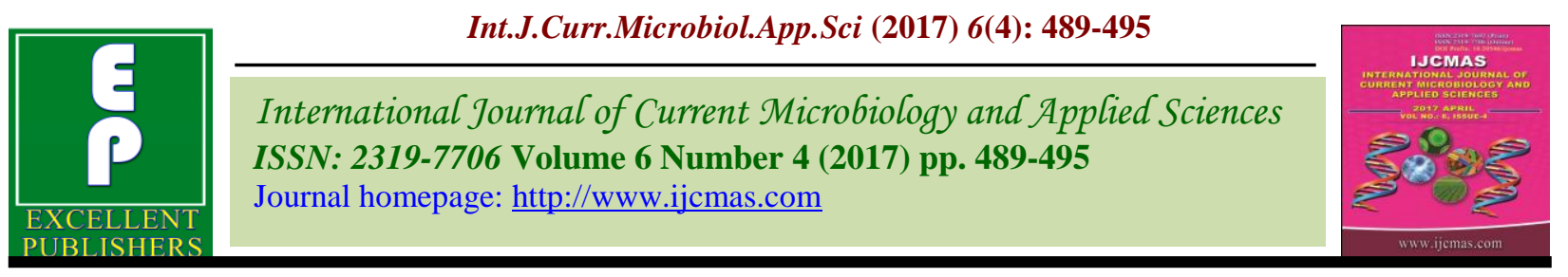

Review Article

https://doi.org/10.20546/ijcmas.2017.604.058

\title{
Tissue Culture of Potato (Solanum tuberosum L.): A Review
}

\author{
Priyadarshani P. Mohapatra* and V.K. Batra
}

Department of Vegetable Science, CCSHAU, Hisar-125001, Haryana, India

*Corresponding author

\begin{tabular}{|c|c|}
\hline & A B S T R A C T \\
\hline Keywords & \\
\hline $\begin{array}{l}\text { Potato, Tissue } \\
\text { culture, in vitro, } \\
\text { Micro-propagation. }\end{array}$ & \multirow{3}{*}{$\begin{array}{l}\text { Plant tissue culture is the method of culturing the plant cells or tissues } \\
\text { under controlled aseptic conditions on a solid or liquid medium. It has } \\
\text { value in basic research for the production of true to type, disease free and } \\
\text { micro-propagated plants. Besides this also has commercial application. This } \\
\text { review work outlines the work done on pertaining to various aspects of in } \\
\text { vitro micro-propagation, regeneration, rooting, hardening, in potato. }\end{array}$} \\
\hline Article Info & \\
\hline $\begin{array}{l}\text { Accepted: } \\
\text { 02 March } 2017 \\
\text { Available Online: } \\
10 \text { April } 2017\end{array}$ & \\
\hline
\end{tabular}

\section{Plant tissue culture of potato (Solanum tuberosum $\mathrm{L}$.)}

Potato can be propagated sexually (by botanical seed, also called true potato seed) and asexually (vegetative) by means of tubers. Seed potato tubers are utilized for multiplication and production (Struik and Wiersema, 1999). This method has a number of disadvantages like low rate of multiplication and high risk of various diseases. Tissue culture techniques have become very popular and alternative means for vegetative propagation of plants in recent years. As an emerging technology, the plant tissue culture has a great impact on both agriculture and industry by providing plants to meet the ever increasing world demand. It has made significant contributions to the advancement of agricultural sciences in recent times and today they constitute an indispensable tool in modern agriculture. It is due to that we can create a large number of clones from a single seed or explants, select desirable traits, decrease the amount of space required for field trials and to eliminate plant diseases through careful selection and sterile techniques. It a biological tool that involves exciting prospects for crop productivity and improvement under aseptic conditions (Jain, 2001). The system is characterized by very flexible rapid multiplication giving a high rate of multiplication in a very short period.

\section{Micro-propagation}

Micro-propagation is a potential biotechnological tool that has become a commercially viable method of in vitro clonal 
propagation of a wide range of herbaceous and woody plants (Garcia et al., 2010). Micro-propagation can be defined as in vitro clonal propagation through tissue culture and rapidly multiplying plant material to produce a large number of progeny plants. This technique was first started by Morel in 1960 for propagation of orchids and is now applied to several plants. It has been proved to be very efficient technique to speed-up the production of high quality pathogen-free plantlets, in terms of genetic and physiological uniformities (Sathish et al., 2011; Supaibulwattana et al., 2011) The term tissue culture techniques covers a wide range of techniques including in vitro culture of organs (shoot tips, root tips, runner tips, stem segments, flowers, anthers, ovaries, ovules, embryos etc.) tissues, cells and protoplasts. In potato, various tissues can be used as explants for shoot generation directly (Anjum and Ali, 2004b). In general, the efficiency of micropropagation depends on a source of explants and explants itself, treatment of explants while preparing them for in vitro culture, composition of culture media, routes of micro propagation 4 followed, and performance of regenerated plantlets. These techniques are becoming useful tools for rapid and clonal multiplication of potato. Since 1902, when Haberlandt conceived the idea of totipotency considerable success has been achieved in the field of plant tissue culture. The commercial feasibility of these techniques has been demonstrated in many diverse plant species including fruit and vegetable plants. For large scale production of uniform, identical seed material of potato, micro-propagation can be the better alternative over conventional propagation of potato. By using the technique, which involves low cost components, largescale clonal material can be produced in short time duration. Use of micro-propagation for commercial seed production has moved potato from test tubes to field. Potato production is being seriously hampered due to certain viruses, fungus and bacterial diseases. Researchers showed that some viruses can decrease the yield by $40 \%$ singly and in combination with other viruses, the loss is 90\% (Siddiqui et al., 1996). Potato virus free clones with meristem culture methods were conducted by Nagib et al. (2003). The organ that is to serve as tissue source, depends upon the physiological or ontogenic age of the organ, the season in which the explants is obtained, the size of explants and overall quality of the parent plant from which the plant is being obtained (Murashige, 1974).

To maintain an aseptic environment, all culture vessels, media and instruments used in handling tissues, as well as explant itself must be sterilized. The importance is to keep the air, surface and floor free of dust. All operations should be carried out in laminar airflow sterile cabinet (Chawla, 2003). For micro-propagation, MS basal medium has proven to be quite effective in several studies (Gopal et al., 1980; Hussey and Stacey, 1981; Aburkhes et al., 1984; Rosell et al., 1987; Ozkaynak and Samanci, 2005). The most important step before the inoculation of explants is surface sterilization. Different sterilization agents can be used like $\mathrm{HgCl}_{2}$ (0.1\%), $\mathrm{NaOCl}\left(5.25 \%\right.$ v/v approx.), $\mathrm{CaOCl}_{2}$ $(0.8 \%$ v/v), $70 \%$ ethanol, $\mathrm{H} 2 \mathrm{O} 2(3-10 \% \mathrm{v} / \mathrm{v})$ etc. The explants of potato were surface sterilized by treating them with sodium hypochlorite $(0.1 \%)$ for 8 minutes, followed by 5 minute wash of savlon, and 30 second wash of $70 \%$ alcohol, at last 6-7 wash of distilled water followed by every treatment (Badoni and Chauhan, 2010). Hoque (2010) have described sterilization treatment for Solanum tuberosum, which includes the surface sterilization by dipping in $0.5 \mathrm{HgCl}_{2}$ solution for 3-5 minute and then washed 6-7 times with autoclaved distilled water. Yasmin et al. (2011) used dissected segments of sprouts as the experimental plant material and were surface sterilized with $10 \%$ commercial 
bleach containing three drops of polyoxyethylene sorbitan monolaurate (Tween-20) for 10 minutes. Explant is of prime importance in their response to tissue culture system for callus initiation and regeneration. The purpose was to compare a range of media and explants to select highly efficient reliable and reproducible regeneration system to maximize the 5 production of regenerates for transformation of new genes to potato plant. Le (1991) also found that when stem section of varieties Bintje and Desiree were cultured, then best growth was shown by explants taken from central portion of the stem in both varieties. The use of single-node cuttings excised from tissue cultured plantlets is more common and avoids the influence of tuber tissue from which sprout sections originate (Mohamed and Alsadon, 2010). Nodal cuttings were also used for auxiliary shoot development and suggested to be the best explants source by several researchers (Roca et al., 1978; Hussey and Stacey, 1981) on either liquid or agar solidified medium. Vanaei et al. (2008) studied the propagation of two commercial cultivars of potato (Marfona and Agria) using meristem tip as explants source. Mohamed et al., (2009) used potato single node as an explant for his experiment. Potato tubers were also used as an explants source (Mutasim et al., 2010). Calli were induced from $1.0 \mathrm{~cm}^{2}$ tuber segment of potato cultivar Almera on MS medium supplemented with different levels of 2, 4-D (1.0-5.0 mg/l). Disease free healthy tubers were propagated on MS media with different concentrations of kinetin (Hoque, 2010). The sprouts were rinsed 3 times with sterile distilled water under the clean bench. Kong et al., (1998) cultured apical meristems of four potato cultivars in modified MS solid medium with BAP, NAA and $\mathrm{GA}_{3}$. They obtained 68.1 - $86.6 \%$ plantlets in 46 - 64 days. They showed that modified medium with NAA is the best for rapidly producing virus free plantlets. In another study, Shibli et al., (2001) subcultured in vitro shoots of Solanum tuberosum L cv. spunta in liquid MS medium containing $0.0,0.5,1.0,1.5$ and $2.0 \mathrm{mg} / \mathrm{l}$ benzyladenine or kinetin. They observed a significant reduction in stem and internodal length by increasing $\mathrm{BA}$ and kinetin concentration in MS medium. BA up to 1.0 and $1.5 \mathrm{mg} / \mathrm{l}$ resulted in an increase in number of proliferating shoots and nodes per culture flask. The use of gibberellins (gibberellic acid, $\mathrm{GA}_{3}$ ), on the other hand have also shown positive effect on micro-propagation in potato as indicated by the study of (Pereira and Fortes, 2003). They developed a protocol for in vitro multiplication of potato in liquid culture medium. The explants of potato (cv. Eliza) with an auxiliary bud were cultured in six different levels of $\mathrm{GA}_{3}$. They observed that full-strength MS medium supplemented with $0.25 \mathrm{mg} / \mathrm{l}$ gibberellic acid, $5.0 \mathrm{mg} / \mathrm{l}$ pantothenic acid, $1.0 \mathrm{mg} / \mathrm{l}$ thiamine and $20 \mathrm{~g} / \mathrm{l}$ sucrose under constant agitation was the most suitable one. In another study, In addition to BA, NAA, 2, 4-D, KIN and $\mathrm{GA}_{3}$, several other plant growth regulators (IBA, IAA, picloram, TDZ) and compounds like chloride were also reported in literature for micropropagation of potato. Incorporation of cytokinin affected the level of endogenous auxin by inhibiting the oxidation of additional IAA, maintaining the optimum level of this auxin for shoot morphogenetic response (Manjula and Nair, 2002). Benzylaminopurine (BAP), zeatin or kinetin added individually to the nutrient medium might stimulate shoot formation. In terms of effectiveness in promoting shoot initiation, reports were contradictory, showing zeatin to be less, equal, or often superior to BA as the cytokinin component (Anjum and Ali, 2004a). $\mathrm{GA}_{3}$ activates the cell division 6 cycle by regulating the transition from $\mathrm{G} 1$ to $\mathrm{S}$ phase, and $\mathrm{G} 2$ to $\mathrm{M}$ phase by the expression of several cyclin-dependent protein kinases (CDKs), which lead to an increase in mitotic 
activity in the intercalary meristem (Fabian et al., 2000). Kong et al. (1998) used apical meristems of potato to initiate in vitro cultures on modified MS solid medium supplemented with BAP, NAA and $\mathrm{GA}_{3}$. Murashige and Skoog (1962) medium supplemented with different combinations of growth regulators has been used for inoculation of multiple shoots in potato. Rout et al. (2001) found that BAP, kinetin and ascorbic acid give best results for regeneration or multiple shoot formation from apical shoots. Shah Zaman et al. (2001) found that the highest stem length and the largest single nodes in potato can be achieved in MS medium containing $0.5 \mathrm{mg} / \mathrm{l}$ NAA. Boston and Demirel (2004) indicated that the best medium for single node culture of potato is MS medium without any growth regulators. Effect of different concentrations of $\mathrm{GA}_{3}$ and $\mathrm{BAP}$ on in vitro multiplication of potato variety Desiree was studied by Asma et al. (2001) they found that maximum shoot length was $8.96 \mathrm{~cm}$ when $4 \mathrm{mg} / \mathrm{l} \mathrm{GA}_{3}$ was used. Maximum number of shoots (14) was obtained when $2 \mathrm{mg} / \mathrm{l}$ BAP was used. Everson and Renan (2003) establish a protocol for propagation of potato in liquid culture with different hormone combination. The MS medium supplemented with $\mathrm{GA}_{3}(0.25 \mathrm{mg} / \mathrm{l})$, panthothenic acid $(5.0 \mathrm{mg} / \mathrm{l})$, thiamine (1.0 $\mathrm{mg} / \mathrm{l})$ and sucrose $(20 \mathrm{~g} / \mathrm{l})$, and under constant agitation, showed high efficiency of the in vitro potato multiplication. Badoni and Chauhan (2010) used low cost alternative to MS salts for shoot proliferation in potato. MS and low cost media with different hormonal combination of KIN (0.04, 0.06 and 0.08 $\mathrm{mg} / \mathrm{l})$ and IAA $(0.50 \mathrm{mg} / \mathrm{l})$ were used. Hoque (2010) observed that MS medium supplemented with $4 \mathrm{mg} / \mathrm{l}$ of KIN showed best performance in respect of multiple shoot regeneration. Raza (2011) studied the effect of different growth regulators (BAP, NAA, $\mathrm{PA}$ and $\mathrm{GA}_{3}$ ) on meristem tip culture of potato and he found that the best regeneration of meristem tips was obtained when MS medium was supplemented with $1.0 \mathrm{mg} / \mathrm{l}$ pantothenic acid $+0.5 \mathrm{mg} / \mathrm{l}$ gibberellic acid. Molla (2011) studied the effect of BAP, TDZ and $\mathrm{ZR}$ on direct regeneration of potato. The MS medium supplemented with $3 \mathrm{mg} / \mathrm{l}$ of BAP, $0.3 \mathrm{mg} / \mathrm{l}$ of $\mathrm{TDZ}$ and $5 \mathrm{mg} / \mathrm{l}$ of $\mathrm{ZR}$ showed very good shoot induction. Farhatullah et al. (2007) reported the affects of different concentrations of $\mathrm{GA}_{3}$ on micropropagation and suggested that the dosage of $0.248 \mathrm{mg} / \mathrm{l}$ of $\mathrm{GA}_{3}$ boosted all the morphological characters over control and other treatments. They suggested that this level $(0.248 \mathrm{mg} / \mathrm{l})$ could be used as standard dose for micro-propagation of potato. Badoni and Chauhan (2009) studied the effect of various growth regulators on meristem tip development and in vitro multiplication of potato cultivar Kufri Himalini. They tried different combinations of growth regulators, e.g., $\mathrm{GA}_{3}$, NAA, and KIN. Results showed that lower concentration of auxin $(0.01 \mathrm{mg} / \mathrm{l}$ NAA) with gibberellic acid $(0.25 \mathrm{mg} / \mathrm{l})$ was the best one for the development of complete plantlets from meristem tips avoiding callus formation and with satisfactory root formation. Cheaper agar alternatives which include various types of starch and gums have been investigated in commercial 7 micropropagation (Nagamori and Kobayashi, 2001). Other options include white flour, laundry starch, semolina, potato starch, rice powder and sago (Prakash et al., 2003). Some researchers used other low cost alternative medium component for in vitro micropropagation of potato (Solanum tuberosum L.). Nyende et al. (2008) used table sugar as a low cost alternative medium component for commercial propagation of potato. Results also showed that table sugar not only enhanced micro-propagation but also significantly lowered the production input costs by $51 \%$ when compared with the analytical grade sucrose. Naik and Sarkar (2001) substituted agar on potato micropropagated medium with $13 \%$ of sago and 
found that the number of shoots and leaves and root length were significantly higher compared to the agar medium. Mohamed et al. (2009) used corn and potato starch as an agar alternative for Solanum tuberosum micro-propagation. The highest number of shoots (6.8) was achieved in medium with 50 or $60 \mathrm{~g} / \mathrm{l}$ of PS $+1 \mathrm{~g} / \mathrm{l}$ of agar. The results suggest that the combination of agar and PS or CS could offer a firm support for plant tissues and could be successfully used for potato micro-propagation. Moeini and Modarres (2003) used different concentration of NAA and BAP for root induction and studied that application of BAP and NAA decreased shooting and rooting of single nodes. Seabrook (2005) reported that in a medium lacking growth regulator, roots form readily on potato plantlets in vitro. Badoni and Chauhan (2010) used MS medium with different concentration of KIN and IAA for root proliferation. All the media used in this study were supplemented with $3 \%(\mathrm{w} / \mathrm{v})$ sucrose, solidified with $0.8 \%(\mathrm{w} / \mathrm{v})$ agar and the $\mathrm{pH}$ was adjusted to $5.8 \pm 0.1$ with $1 \mathrm{M}$ $\mathrm{NaOH}$ before autoclaving at $121^{\circ} \mathrm{C}$ and $15 \mathrm{lb}$ psi for $15 \mathrm{~min}$. Acclimatization were done when In vitro rooted plants of potato were removed from rooting medium and washed to remove adhering gel and transplanted to plastic pots containing autoclaved garden soil and sand at 3:1 ratio and covered with bottle. Plants were kept under culture room conditions for 15 days then transferred to green house and placed under shade until growth was observed.

\section{References}

Aburkhes, M., Fahmi, N., Benhemida, A., Nafali, M. and Zeiglem, A. 1984. Virus free potatoes by tissue culture. Acta horticulturae, 289: 77-79.

Anjum, M.A. and Ali, H. 2004a. Effect of culture medium on shoot initiation from calluses of different origin in potato (Solanum tuberosum L.). Biotechnol., 3:
194-199.

Anjum, M.A. and Ali, H. 2004b. Effect of culture medium on direct organogenesis from different explants of various potato genotypes. Biotechnol., 3: 187-193.

Asma, R., Askari, B., Abbasi, N.A., Bhatti, M.and Quraishi, A. 2001. Effect of growth regulators on in vitro multiplication of potato. Int. J. Agri. Biol., 3: $181-182$

Badoni, A. and Chauhan, J.S. 2009. Effect of Growth Regulators on meristem-tip development and in vitro multiplication of Potato cultivar. Kufri Himalini. Nature and Sci., 7(9): 31-34.

Badoni, A. and Chauhan, J.S. 2010. In vitro Sterilization Protocol for Micropropagation of Solanum tuberosum cv. Kufri Himalini. Academia Arena, 2(4).

Bostan, H. and Demirel, E. 2004. Obtaining PVX, PVY and PLRV-free micro tuber from Granola, Pasinler 92 and Casper potato (Solanum tuberosum L.) cultivars. Pak. J. Biol. Sci., 7(7): 1135-1139.

Chawla, H.S. 2003. Plant Biotechnol., Laboratory manual for plant biotechnology, Oxford and IBH Publishing Co. Pvt. Ltd. New Delhi.

Fabian, T., Lorbiecke, R., Umeda, M., and Sauter, M. 2000. The cell cycle genescycAl; 1 and $c d c 2 O s-3$ are coordinately regulated by gibberellin in planta. Planta., 211: 376.383.

Farhatullah, Abbas, Z. and Abbas, S.J. 2007. In vitro Effects of Gibberellic Acid on Morphogenesis of Potato Explant. Int. J. Agri. Biol., 1: 181-182.

Garcia-Gonzales, R., Quiroz, K., Carrasco, B. and Caligari, P. 2010. Plant tissue culture: Current status, opportunities and challenges. Cienciae investigación agraria, 37(3): 5-30.

Gopal, J., Minocha, J.L. and Dhaliwal, H.S. 1980. Microtuberization in potato (Solanum tuberosum L.). Plant Cell Reports, 17: 794-798.

Haberlandt, G. 1902. Culturversuche mit isolierten Pflanzenzellen. Sitz-Ber. Mat. 
Nat. K1. Kais. Akademie der Wissenschaften in Wien, 111: 69.92.

Hoque, M.E. 2010. In vitro tuberization in potato (Solanum tuberosum L.). Plant Omics J., 3: 7-11.

Hoque, M.E. 2010. In-vitro regeneration potentiality of potato under different hormonal combination. World J. Agri. Sci., 6(6): 660-663.

Hussey, G. and Stacey, N.J. 1981. In vitro propagation of potato (Solanum tuberosum L.). Annals of Bot., 48: 787796.

Jain, S.M. 2001. Tissue culture-derived variation in crop improvement. Euphytica, 118: 153-166.

Kong, X.S., Zhang, M.X. and Guo, X.P. 1998. Studies on apical meristem culture and rapid propagation techniques for potatoes. Acta Agriculturae Universitatis Henanensis, 32: 133-137.

Le, C.L. 1991. Practical aspects of potato (Solanum tuberosum L.) micropropagation. Revue Suisse d' Agri., 23: 357-358.

Manjula, S. and Nair, G.M. 2002. High frequency plantlet regeneration via organogenesis in (Solanum tuberosum L.) aculeatissimum Jacq. and possible exploitation of solasodine. J. Plant Biol., 29: 23-2.

Mohamed, M.A.H. and Alsadon, A.A. 2010. Influence of ventilation and sucrose on growth and leaf anatomy of micro propagated potato plantlets. Scientia Horticulturae, 123: 295-300.

Moeini, M.J. and Modarres, S.S.A.M. 2003. Effects of Different Hormone Combinations and Planting Beds on Growth of Single Nodes and Plantlets Resulted from Potato Meristem Culture. Plant Tissue Culture, 13(2): 145-150.

Moeini, M.J., Armin, M., Asgharipour M.R. 2011. Effects of Different Plant Growth Regulators and Potting Mixes on Micropropagation and Mini-tuberization of Potato. Plantlets Adv. Environ. Biol., 5(4): 631-638.

Mohamed, M.A.H., Alsadon, A.A. and $\mathrm{Al}$
Mohaidib, M.S. 2009. Corn and potato starch as an agar alternative for (Solanum tuberosum L.) micropropagation. African J. Biotechnol., 9(1): 12-14.

Molla. 2011. Effect of Growth Regulators on Direct Regeneration of Potato, Int. Conference on Environ. Industrial Innovation IPCBEE (12) IACSIT Press, Singapore.

Morel, G. 1960. Producing virus-free cymbidiums. American Orchid Society, 29: 495-497.

Murashige, T., and Skoog, F. 1962. A revised medium for rapid growth and bioassays with tobacco cultures. J. Plant Physiol., 15: 473-479.

Murashige, T. 1974. Plant propagation through tissue cultures. Annual Review of Plant Physiol., 25: 135-166.

Mutasim, M.K., Abdelaleem, K.G. and Rasheid, S.M. 2010. Callus formation and organogenesis of potato (Solanum tuberosum L.) cultivar almera. J. Phytol., 2(5): 40-46.

Nagamori, E. and Kobayashi, T. 2001. Viscous additive improves micropropagation in liquid medium. J. Biosci. Bioengi., 91: 283-287.

Nagib, A., Hossain, S.A., Alam, M.F., Hossain, M.M., Islam, R. and Sultana, R.S. 2003. Virus free potato tuber seed production through meristem culture in tropical Asia. Asian J. Plant Sci., 2(8): 616-622.

Naik, P.S. and Sarkar, D. 2001. Sago: an alternative cheap gelling agent for potato in vitro culture. Biologia Plantarum, 44: 293-296.

Nyende, A.B. 2008. Table sugar as an alternative low cost medium component for in vitro micropropagation of potato (Solanum tuberosum L.). African $J$. Biotechnol., 7(15): 2578-2584.

Ozkaynak, E. and Samanci, B. 2005. Yield and yield components of greenhouse, field and seed bed grown potato (Solanum tuberosum L.) plantlets. Ziraat Fakültesi Dergisi - Akdeniz Üniversitesi, 18:125129.

Pereira, J.E.S. and Fortes, G.R. 2003. Protocol 
for potato propagative material production in liquid medium. Pesquisa Agropecuária Brasileira, 38(9): 10351043.

Raza, S. 2011. Effect of growth regulators on meristem tip culture of local potato cvs desiree and patrones. Pak. J. Agri. Engi. Vet. Sci., 27(2): 143-149.

Roca, W.M., Espinoza, N.O., Roca, M.R. and Bryan, J.E. 1978. A tissue culture method for rapid propagation of potatoes. American Potato J., 55(12): 691-701.

Rosell, G., De Bestoldi, F.G. and Tizio, R. 1987. In vitro mass tuberization as a contribution to potato micro propagation. Potato Res., 30(1): 111-116.

Rout, G.R., Palai, S.K., Samantaray, S. and Das, P. 2001. Effect of growth regulator and culture conditions on shoot multiplication and rhizome formation in ginger (Zingiber officinale Rosc.) in vitro. In vitro Cellular and Development Biol. Plant, 37: 814-819.

Shah Zaman, M., Quraishi, A., Hassan, G., Sardar, R., Khabir, A. and Gul, N. 2001. Meristem Culture of Potato (Solanum tuberosum L.) for Production of VirusFree Plantlets. On Line J. Biol. Sci., 1(10): 898-899.

Sathish, S.S., Janakiraman, N., Johnson, M. 2011. In vitro propagation of Aristolochia bracteat Retz. A medicinally important plant. Biotechnol. Res. Int., 2: 44-52.

Shibli, R.A., Abu-Ein, A.M. and Mohammed, M.A. 2001. In vitro and in vivo multiplication of virus free. Spunta potato. Pak. J. Botany, 33(1): 35-41.

Siddiqui, S.U., Chaudharay, M.F. and Anwar, R. 1996. In vitro preservation of potato (Solanum tuberosum L.) germplasm. Pak. J. Botany, 28: 37-40.

Struik, P.C. and Wiersema, S.G. 1999. Seed Potato Technology. Wageningen Academic Publishers, The Netherlands, pp. 383.

Supaibulwattana, K., Kuntawunginn, W., Chaum, S. and Kirdmanee, C. 2011. Artemisinin accumulation and enhanced net photosynthetic rate in Qinghao Artemisia annua L.) hardened in vitro in enriched-CO2 photoautotrophic conditions. Plant Omics J., 4: 75- 81.

Vanaei, H., Kahrizi, D., Chaichi, M., Shabani, G. and Zarafshani, K. 2008. Effect of Genotype, Substrate Combination and Pot Size on Minituber Yield in Potato (Solanum tuberosum L.). AmericanEurasian J. Agri. Environ. Sci., 3(6): 818821.

Yasmin, A., Jalbani, A. and Raza, S. 2011. Effect of growth regulators on meristem tip culture of local potato cvs desiree and patrones Pak. J. Agri. Agri. Engi. Vet. Sci., 27(2): 143-149.

\section{How to cite this article:}

Priyadarshani P. Mohapatra and Batra, V.K. 2017. Tissue Culture of Potato (Solanum tuberosum L.): A review. Int.J.Curr.Microbiol.App.Sci. 6(4): 489-495.

doi: https://doi.org/10.20546/ijcmas.2017.604.058 